Marija Rakić

Bojan Krstić ${ }^{2}$

University of Niš, Faculty of Economics

Tamara Rađenović 3

University of Niš, Faculty of Occupational Safety
P. $37-48$

SCIENTIFIC REVIEW PAPER

DOI: $10.5937 / \mathrm{ESD} 2102037 \mathrm{R}$

Received: February 5, 2021

Accepted: April 28, 2021

\title{
MEASURING ENERGY EFFICIENCY OF AN ENTERPRISE
}

\begin{abstract}
Energy efficiency is gaining in importance as part of environmental efficiency within sustainable development. Many enterprises realize the need for the reduction of energy costs and improved control of energy consumption. This can be achieved by implementing the concept of energy efficiency. The subject of research in this paper is the analysis of the way in which energy efficiency can be measured within an enterprise. Therefore, the aim of the research is to define a set of indicators for measuring energy efficiency in an enterprise, as well as to point out cost advantages and competitiveness that are achieved by applying energy efficiency management.
\end{abstract}

Key words: energy efficiency, measuring, energy costs, buildings, sustainable development.

JEL classification: M21, Q40, Q56

\section{МЕРЕЊЕ ЕНЕРГЕТСКЕ ЕФИКАСНОСТИ ПРЕДУЗЕЋА}

\section{Апстракт}

Енергетска ефикасност добија све више на значају као део еколошке ефикасности у оквиру одрживог развоја. Велики број предузећа увиђа потребу за смањењем трошкова енергије и бољом контролом потрошње енергије. То се може постићи имплементацијом кониепта енергетксе ефикасности. Предмет истраживања у овом раду јесте анализа начина на који се енергетска ефикасност може измерити. Стога је ичиљ истраживања дефинисање сета индикатора за мерење енергетске ефикасности, као и указивање на трошковне предности и конкурентност које се остварују адекватним управљањем енергетском ефикасношћу.

Кључне речи: енергетска ефикасност, мерење, трошкови енергије, зграде, одрживи развој.

\footnotetext{
${ }^{1}$ marijamptrakic@gmail.com, ORCID ID 0000-0001-5997-0501

${ }^{2}$ bojan.krstic@eknfak.ni.ac.rs, ORCID ID 0000-0003-4597-6819

${ }^{3}$ tamara.radjenovic@znrfak.ni.ac.rs, ORCID ID 0000-0003-1632-7772
} 


\section{Introduction}

There are increased number of enterprises which within their mission, vision and strategy create a business policy that contributes to sustainable development. Due to the higher cost of fossil fuels, economic crises, new environmental and energy standards, enterprises should focus more and more attention to energy saving, the elimination of losses and inefficiency, and the control of energy consumption. The concept of energy efficiency has, therefore, become an integral part of operation of every enterprise which tends to maintain its competitiveness. The effects of an irrational use of natural resources are farreaching, especially non-renewable resources. They can negatively affect the environment in which the enterprise operates, as well domestic economies of countries and the global image of the world. On the other hand, the application of the concept of social responsibility and energy efficiency contributes to economic development and sustainability.

Considering the significance of energy efficiency regarding sustainable development, it is necessary to efficiently manage the use of energy in enterprises. It is particularly important to consider the aspects of operation in which energy efficiency affects the total expenses and profitability. From a corporate perspective, the value which is gained by applying the concept of energy efficiency should be manifested through the environment in which an enterprise operates, as well as through the profit it achieves. In order to be clearly and precisely determined, the value should be visible and properly quantified or described. Due to this, an adequate set of quantitative and qualitative indicators is needed in order to provide energy efficiency measurement. By measuring energy efficiency, the difference in the way an enterprise operates before and after the use of this concept can be clearly pointed out, as well as the numerous advantages for the enterprise and its surroundings (living and natural environment and resources).

The aim of this paper is to determine the concept of energy efficiency, to point out the set of indicators for the energy efficiency measurement and the elements it consists of in order to gain insight into the effects of energy efficiency on the operation of a certain enterprise, as well as the numerous advantages for the enterprise and the environment in which it operates, which are achieved by an adequate and complete application of the concept of energy efficiency.

\section{The concept of energy efficiency and a general approach to the quantification of energy efficiency}

The concept of sustainable development implies sustainable development in environmental, economic, social, cultural, and international aspects. Numerous studies indicate the disruption of the natural balance, and that consequences of the behaviour which neglects the long-term influence on the environment can be dangerous. Therefore, more and more enterprises tend to implement the concept of sustainable development into their mission, vision and strategy. The ecological sustainable development is measured through eco-efficiency, i.e. environmental efficiency. Environmental efficiency points out the use of natural resources and the negative aspects of that use. The essence of ecoefficiency also represents energy efficiency. 
Energy efficiency is the focus of the management of enterprises which desire to continually improve their business activities. Numerous advantages which originate from the implementation of the concept of improving energy efficiency as business (as well as environmental) performances are the following: greater cost efficiency, better competitive position on the market, greater energy security, environmental benefits, etc.

Economic efficiency represents a quantitative relationship between outputs and inputs. If this efficiency coefficient is multiplied by $100 \%$, the result represents the degree of efficiency (Krstić, Sekulić, 2020):

\section{(1) Economic efficiency $=($ Outputs / Inputs) $\times 100 \%$}

The efficiency measure structured in this way, provides an answer to the following question: how much input (resource) is needed to achieve a certain level of output? In other words, it shows how many units of output (results) are created by one unit of investment (input). This general formula can be used to determine the indicators of environmental efficiency and energy efficiency.

Environmental efficiency determines the success in the realisation of environmental activities, programs and initiatives. Namely, eco-efficiency means "to do something in the right way". This goes with a tendency, i.e. an aim to reduce negative influences on the environment. The essence is to use as small inputs as possible that are already invested into the realisation of environmental activities, in order to achieve as big (good) environmental effects as possible. Eco-efficiency is quantitatively measured as a relevant relation between certain categories of effects and inputs (Krstić, Sekulić, 2020):

(2) Eco-efficiency $=$ (Realised environmental effects / Inputs for the realisation of environmental initiatives, activities and programs of an enterprise) $x 100 \%$

Energy efficiency (Forsström et al., 2011, p. 13) is the quotient of the output (which is expressed as a certain volume of products/services) and the input (the energy which is needed for the production of the specific output):

\section{(3) Energy efficiency = (Production volume i.e. Service volume / Energy consumption for the realisation of the output) $\times 100 \%$.}

The concept of energy efficiency specifically emphasises the following:

- the possibility of turning one form of energy into the other,

- ecological effects on the environment which are accomplished by its implementation,

- the use of a smaller amount of energy for the production of the same volume of products/services,

- the possibility of reducing the cost of energy, which is, perhaps, the most significant for enterprises which continually work on improving their business.

The application of the concept of improving energy efficiency implies numerous advantages for the enterprise which invests into the application of this concept. Besides energy saving, there are many other additional advantages which are reflected on the enterprise's business activities and lead to its prosperity, including the increase in productivity, product quality, efficiency, the improvement of work and life surroundings. 
The productivity of production is increased, which is the result of lower processing costs. The satisfaction of buyers is higher because they receive a product/service of higher quality. The reliability and the production volume are also increased. Energy efficiency contributes to general efficiency, because its application leads to a better use of production capacities and equipment and it shortens the time which is needed for the implementation of production processes and operations. In this way, the total cost of production is reduced, as well as the overuse of machines and production equipment, the need for cooling, the need for workforce and control by an engineer (Pye, McKane, 2000). The application of energy efficiency leads to the reduction of waste which occurs during the production process, as well as the reduction of hazardous waste which reduces the costs of waste disposal. Also, water is used more efficiently. The amount of waste waters is reduced, as well as the loss of water (Finman, Laitner, 2001).

One of the advantages of the concept of energy efficiency is the improvement of work environment because the amount of noise during production processes is reduced, lighting is improved, temperature control is improved, air quality is better, etc. Safety during the production process is increased. The employees have a more comfortable workplace (Skumatz et al., 2000).

Energy efficiency has a positive effect on the environment and the health of people, due to the fact that the implementation of this concept implies the reduced emission of $\mathrm{CO} 2$. A positive impact on the environment by a consistent application of the concept of energy efficiency within the enterprises' business practices implies reduced air pollution, improved local air quality in those areas where the production occurs, reduced emissions of harmful matters which affect the environment and the health of people (Worrel et al., 2003).

Other advantages of applying energy efficiency that should also be emphasised are increased motivation in employees, better reputation of enterprises, postponed or reduced capital expenses, spare spaces, improved competitiveness, reduced legal risks, risks of changes in the cost of energy and commercial risks, the increased value of shares, etc. (Cooremans, 2011).

\section{Energy efficiency measurement}

The indicators of energy efficiency measurement differ in regard to the aspect from which energy efficiency is observed (economic, environmental, social, etc.). Also, the level on which the concept is applied is also important (micro - an enterprise, or macro - a community).

Patterson (1996, p. 378) emphasises four groups of indicators of energy efficiency: "thermodynamic, physical-dynamic, economic-thermodynamic and economic". Thermodynamic indicators are based on the thermodynamic values of inputs and outputs (for example, thermal efficiency of heating). Physical-thermodynamic indicators measure energy inputs in thermodynamic values, whereas outputs are measured in physical units (for example, the energy consumption by a square meter in a building). Economic-thermodynamic indicators use the expression of outputs (merchandise, product and services) in market costs, and the energy (input) is expressed in thermodynamic 
measuring units (e.g. the energy intensity of $\mathrm{GDP}^{4}$ ). Economic indicators are such indicators in which the inputs and outputs are expressed in a financial expression (e.g. the energy consumption per unit of GDP).

For the definition of a specific indicator of energy efficiency (provided by the relation No. 3), with the purpose of adequate and precise measurement, it is necessary to determine the input and the output. The question is what the output could be in this expression of energy efficiency, if the input is the quantifier of this indicator. During the expression of the input for energy efficiency measurement (Forsström et al., 2011, p. 20) the consumed energy within the life cycle of a product should be taken into consideration, as well as the energy which obtained its physical form in the materials (outcomes), and the energy from recycled materials. When it comes to the corporate measurement of energy efficiency, it is very important to have energy costs as an information input, based on the amount of consumed energy and the energy cost per unit of consumed amount. The output is usually the amount of product (production) or the scope of a provided service. Regarding the expression of the output for energy efficiency measurement, it should be noted that a simple measurement of the amount of production cannot take into account the quality of a service or a product (Forsström et al., 2011, p. 20).

The control of energy efficiency requires the use of a set of indicators; however, the focus are the two key, initial, indicators such as:

- Energy natural productivity,

- Energy financial productivity.

Energy natural productivity indicates the production volume per unit of consumed energy. In other words, it shows the amount of consumed energy (for example, expressed in kilowatt-hours). This indicator is calculated in the following way:

\section{(4) Energy natural productivity $=($ Production Volume $/$ Energy Consumption $) \times 100 \%$}

Energy financial productivity shows the quotient of the production volume and total energy costs (Benedetti et al., 2015, p. 44) within a certain time period $t$ :

(5) Energy financial productivity $=($ Production volume $/$ Total energy costs) $\times 100 \%$

This ratio shows what amount of a production volume is achieved per 100 monetary units of total energy costs.

Besides the aforementioned two indicators, analytically speaking energy cost efficiency is a particularly important indicator. Essentially, this is not a new indicator in relation to the two indicators previously explained. From a mathematical perspective, energy cost efficiency is an inverse value of the indicator of energy financial productivity. The indicator of energy cost efficiency is, in essence, an indicator of financial energy efficiency, because it takes into account the costs of energy and not the consumption of energy (as a physical measure of consumed energy). Energy cost efficiency is calculated as a quotient of total energy costs and a production volume:

(6) Energy cost efficiency $=($ Total energy costs / Production volume) $\times 100 \%$

\footnotetext{
${ }^{4}$ The energy intensity of GDP is calculated as a quotient of energy consumption and the GDP value (it represents an inverse value of energy productivity, which is calculated as a quotient of the GDP value and energy consumption). This indicator shows how much energy is spent for the production of one unit of GDP.
} 
This indicator shows what amount of energy is spent on the production of one unit of products. In other words, this performance indicator shows how many monetary units of energy cost have been paid for the generated production (production volume) which is expressed in physical units of a specific product.

Energy cost efficiency can be disaggregated into two indicators. Namely, it can be calculated as a multiplication of two indicators (Benedetti et al., 2015, p. 44) such as: 1. Cost of energy to energy consumption ratio which represents the quotient of total energy costs and energy consumption (the amount of consumed energy) and 2. Energy consumption to production volume ratio which is calculated as a quotient of consumed energy and production volume.

Therefore, the energy cost efficiency can be expressed in the following way:

(7) Energy cost efficiency $=$ (Cost of energy to energy consumption ratio $x$ Energy consumption to production volume ratio) $\times 100 \%$

i.e.

(8) Energy cost efficiency $=[($ Total energy costs / Energy consumption) $x$ (Energy Consumption / Production volume)] x 100\%.

Building Assets are part of the fixed assets of enterprises. Buildings are also consumers of different energy, considering the characteristics and the purpose of building assets (production, selling, administrative, storage, etc.) It is interesting to supplement the previous set of indicators of energy efficiency of buildings (work spaces) as a significant asset of an enterprise. When it comes to buildings, the consumption of energy, and, at the same time, the potential for the implementation of the concept of improvement of energy efficiency, is very large. Buildings as consumers of energy imply direct consumption which is related to heating and cooling, and indirect consumption which refers to the consumption of electric energy for lights, appliances, office equipment, cooling devices, cooking and engines in pumps and ventilation systems.

The measurement of energy efficiency of buildings includes the selection of an appropriate set of indicators. However, making the right selection of indicators depends on the fact what data, for what purpose and who needs them (owners, lessees, contractors, etc.).

Energy Consumption per square meter is calculated in the following way (Forsström et al., 2011, p. 38):

(9) Energy Consumption per square meter = Energy Consumption / Building Surface,

Energy Consumption or the amount of consumed energy in kilowatt-hours is calculated for a one-year period; however, this period can be shorter, six or three months. The square footage of a building can include only the area which is heated or a total footage, and it is expressed in square metres.

Energy consumption adjusted for the utilization rate of a building is an indicator which refers to the degree (rate) of the utilisation of a space. This rate, logically, affects the energy efficiency. This indicator is calculated in the following way (Forsström et al., 2011, p. 39):

(10) Energy consumption adjusted for the utilization rate of a building = Energy consumption / (Utilization Rate of a building x Building square footage) 
Utilization rate of a building is calculated as the quotient of the number of hours of the actual use of space (building) during 24 hours of one day and the maximum number of hours of the use of the same space (building) during 24 hours of one day. Energy efficiency will be higher if the rate of the utilisation of space is higher. Namely, energy consumption in buildings implies some basic consumption of energy which occurs regardless of the use of a building (heating, minimum ventilation and other continual energy services) and the consumption of energy by the occupants of the building.

Intensity of energy consumption is an indicator which is used for the calculation of the amount of consumed energy depending on the number of hours which an individual spends in the building (Forsström et al., 2011, p. 40). It is calculated in the following way:

(11) Intensity of energy consumption = Energy Consumption / Number of hours a person or people spent in the building

This indicator shows to what extent a certain space is used efficiently; however, it is not suitable for comparing different buildings or buildings with different purposes.

Economic Intensity of Energy consumption (Forsström et al., 2011, p. 41) is an indicator which is used for the calculation in leased buildings because they are not owned by enterprises. This is calculated in the following way:

(12) Economic Intensity of Energy consumption = Energy consumption / Rent for the particular business space, i.e. building

The rent for a specific space, i.e. building is used for the calculation of this indicator as the amount which is paid for the period in which the amount of consumed energy is measured. The rent which is paid by the user of a certain building, implies a minimum benefit which the user expects from that space. If the user (lessee, the one who pays the rent) believes that the rent surpasses the usefulness which is achieved by the use of the building (space), most probably it will not be the user in the future. Taking this into consideration, this indicator shows the relation between the consumed energy and the usefulness which is achieved by a specific space for a specific time period. The lower value of this indicator points to higher energy efficiency.

Besides the aforementioned indicators, it is also important to use Energy consumption - benchmark performance index. It is calculated in the following way:

(13) Energy consumption - benchmark performance index = Energy consumption for a particular building / Energy consumption of a similar building that uses the best technology

A higher value of this indicator implies a higher potential for energy saving, i.e. for the implementation of proper technology which will save energy in the future. The best possible technology with which a certain space (building) is equipped is the technology which is available on the market and represents a favourable investment for an enterprise (Forsström et al., 2011, p. 42). 


\section{Energy efficiency management}

Energy costs are expressed in monetary units, the production volume is expressed in physical units of produced products, and the consumption of energy is expressed in kilowatts, for example. Energy costs are complex. They are directly connected with energy consumption, but they are also affected by different price tariffs and the flows of offers and demands on the energy market (the market of fuels). All this should be taken into consideration when defining a specific corporate strategy which adheres to the concept of energy efficiency with the aim of reducing total energy costs to the lowest level possible.

When it comes to the Cost of energy to energy consumption ratio, its value depends on the choice of a suitable tariff and the choice of suppliers, the respect of contract rules of ordering from a supplier, as well as the needed amount of energy (Benedetti et al., 2015). The selection of a suitable price tariff and the selection of suppliers implies that the enterprise should sign the most favourable contract regarding the purchase of energy with the suppliers of energy, i.e. the contract with the lowest price possible, while taking into consideration the corporate energy consumption and the fuel market. The factors which affect the selection of an appropriate price tariff and suppliers are: a) a total energy consumption, because the use of the effect of volume economy provides a certain benefit - the purchase of a larger amount of energy will provide lower costs per kilowatt hours, and b) the estimation of whether the demand for energy is small, balanced, or big, in order to provide it on time, etc.

Obeying the contract rules of purchase is necessary, in order to avoid penalties if there is a breach of contract. The required amount of energy implies that it should be taken into account how much energy is actually needed for production by a specific enterprise, and, according to this, a certain amount of energy should be arranged and purchased.

On the other hand, the value of energy consumption to production volume ratio is affected by the transformation, distribution and consumption of energy (Benedetti et al., 2015).

The process of energy transformation implies the shift of one form of energy into the other form, so that a certain source of energy can be used in the most efficient way, with the elimination of energy losses during the production process in a particular enterprise. The process of energy distribution implies a delivery of energy to the locations where it is needed, so it can be used in the most efficient way, with the elimination of energy losses. The process of energy consumption implies the use of energy in an efficient and effective way.

When deciding on the set of programs which will be used for the implementation of the concept of energy efficiency, the effects which will influence the energy demands should also be taken into consideration, as well as the energy consumption management. There are three main categories of the effects of applying the program of energy efficiency, and they are (Benedetti et al., 2015):

- Change in the necessary amount of energy,

- Change of the profile of energy demand, and

- Partial or complete isolation from energy supply network. 
1. The change in the needed amount of energy implies that the amount of energy which is needed for the functioning of the production system at a desired level is smaller in relation to the amount of energy which was needed before the implementation of the program of energy efficiency (Benedetti et al., 2015). The programs (measures) which enable this effect are implemented in the following areas: transition to a more energy-efficient production and other equipment which has the influence on the appropriate selection of suppliers and price tariffs, as well as the adherence to the contract rules regarding the purchase of energy which affect the value of cost of energy to energy consumption ratio; the selection of the appropriate production technology, the selection of techniques which affect the transformation, distribution and consumption of energy, which also affect the value of the indicator energy consumption to production volume ratio.

2. The change in the profile of energy demand implies that after the introduction of the program (measures) for achieving desired energy efficiency of the production system, the use of energy in different periods is required (throughout the day, as well as throughout the year) (Benedetti et al., 2015).

Measures which can provide this effect are applied in the following areas: the total consumption of energy, the highest demand for energy, a response to the demand and the appropriate flexible systems of energy costs which affect the proper selection of an energy supplier and the price tariff, the adherence to the contract rules of the purchase and the needed amount of energy for the production process at a certain location and a certain time, which affect the value of the indicator cost of energy to energy consumption ratio.

Besides these measures, the following measures which affect the value of energy consumption to production volume ratio, are also relevant: a) the selection of a modulation technique and dimensioning, which affect the transformation, distribution and consumption of energy during the design stage, b) the best practices, c) monitoring and controlling which affect the transformation, distribution and consumption of energy during the stages of production and maintenance.

3. Partial or total isolation from the supply network implies that after the application of measures for achieving desired energy efficiency of a production system there is no need for energy from the supply network, or that, only occasionally, there is the need to use the supply network (Benedetti et al., 2015). Measures which can provide this effect have an influence on the needed amount of energy which affects the value of the indicator cost of energy to energy consumption ratio.

Every effective program of energy efficiency management includes certain stages, and they are: a) the stage of management commitment, b) the stage of control (revision) and analysis, c) the stage of implementation (Goswami, Kreith, 2007).

The stage of management commitment implies the inclusion of the corporate management team and the assignment of specific tasks whose fulfilment leads to the implementation of the program of energy efficiency. Afterward, it is important to select a manager who will be the program coordinator, and to form the board for the implementation of the program, as well as to name representatives for organisational segments of an enterprise, who are the board members and who are directly involved in the realisation of the program. 
The stage of control (revision) and analysis of the implementation of the program of energy efficiency implies, first of all, the review of energy efficiency indicators, a preliminary analysis of the records of indicators from the previous period, and the specification of necessary resources. It is also necessary to perform a comparative analysis of data from different years. After that, it is necessary to analyse different options of the program of energy efficiency management from an economic aspect.

The implementation stage implies setting goals for the enterprise and for every organisational part, determining the funds needed for the investment into a certain program and setting priorities in the realisation of different defined projects It is also necessary to establish a quality system of measuring energy efficiency indicators and reporting on energy efficiency performance, continual monitoring and control. It is particularly important to promote the program throughout the organisation and to talk about its importance with the employees, and, in that way, influence their awareness and engagement regarding the implementation. Finally, it is important to periodically perform an evaluation of the program of energy efficiency management and, if necessary, to conduct proper corrections in the program, in order to overcome perceived issues and limitations identified during the program implementation.

When it comes to energy efficiency management, it is important to say that there are certain stimuli for enterprises in order for them to decide about the implementation of this concept. In this sense, the importance of financing the program of energy efficiency by the state should be pointed out, as well as the significance of external pressures such as the increase in energy costs and the introduction or the increase in fees for the used resources and for the emission of pollutants.

However, despite the importance of the implementation of the concept of energy efficiency, there are barriers which slow down or disable its application. One of them is certainly a high investment into these programs. The lack of capital slows down the adoption of measures of energy efficiency. Subventions or affordable loans can help in speeding up the spread of measures of energy efficiency. Also, the quality of the control of energy consumption influences the application of the program (measures) for the achievement of a higher level of energy efficiency. Therefore, it is necessary for the efficient regulation to include quality standards for the control of energy consumption (Fleiter et al., 2012).

Studies also show that enterprises have a favourable attitude towards energyefficient technologies which are able to provide long-term benefits, which proves their willingness to adopt solutions if they can improve their long-term competitiveness. Other initiators which are viewed as strategic for the improvement of energy efficiency are business initiatives in the enterprise and the management team who is dedicated to a successful application of the concept of energy efficiency (Cagno, Trianni, 2013).

\section{Conclusion}

There are increased number of enterprises which understand the significance of the implementation of the concept of improving energy efficiency for the profitability of their business, as well as numerous benefits of this concept for the environment. In 
order for the enterprises to properly utilise all the advantages of the implementation of this important concept for the entire economic efficiency, it is necessary that they formulate and implement the strategy of energy efficiency and programs for the energy efficiency management which will support the implementation of the aforementioned strategy. Taking into account numerous advantages which are provided to enterprises by the implementation of the concept of energy efficiency and to the environment in which they operate, it is necessary to emphasise its significance. The significance of energy efficiency can be understood through the quantification of the effects reached by its implementation. That is why it is important to establish an appropriate system of energy efficiency measurement which should be an informational input for efficient energy efficiency management.

The efficiency of the use of energy is different in different industries because they imply different products and processes. Taking into account that particular diversity, the programs of energy efficiency management are specific for different industries, as well as different enterprises within one industry. Many large enterprises have succeeded in accomplishing great savings in the consumption of fuels and electric power by applying different programs of energy efficiency management. Smaller enterprises, however, can face certain difficulties during the implementation of these programs, due to the lack of knowledge, competencies, technical staff and equipment which are necessary for an effective realisation of the program of energy efficiency. One of the possible solutions of the aforementioned limitations can be to hire external consultants and experts. Besides a high-quality strategy of energy efficiency, it is also necessary to have a good organisation for a successful implementation of the program of energy efficiency, and it is important to provide motivation and dedication of employees and the support of corporate management.

\section{Reference}

Benedetti, M., Cesarotti, V., \& Introna, V., (2015). Improving energy efficiency in manufacturing systems - literature review and analysis of the impact on the energy network of consolidated practices and upcoming opportunities. In: M. Eissa (Eds), Energy Efficiency Improvements in Smart Grid Components (pp. 41-68). London, England: Intech Open Limited.

Cagno, E., \& Trianni, A. (2013). Exploring drivers for energy efficiency within small-and medium-sized enterprises: first evidences from Italian manufacturing enterprises. Applied Energy, 104, 276-285.

Cooremans, C. (2011). Make it strategic! Financial investment logic is not enough. Energy Efficiency, 4(4), 473-492.

Finman, H., \& Laitner, J. A. (2001, July). Industry, energy efficiency and productivity improvements. In Proceedings of the 2001 ACEEE Summer Study on Energy Efficiency in Industry, 561-570.

Fleiter, T., Schleich, J., \& Ravivanpong, P. (2012). Adoption of energy-efficiency measures in SMEs - An empirical analysis based on energy audit data from Germany. Energy Policy, 51, 863-875. 
Forsström, J., Lahti, P., Pursiheimo, E., Rämä, M., Shemeikka, J., Sipilä, K., Tuominen P., \& Wahlgren, I. (2011). Measuring energy efficiency: Indicators and potentials in buildings, communities and energy systems. Vuorimiehentie, Finland: VTT Technical Research Centre of Finland.

Goswami, D. Y., \& Kreith, F. (Eds.). (2007). Handbook of energy efficiency and renewable energy. New York, USA: Crc Press.

Krstić, B., \& Sekulić, V. (2020). Upravljanje performansama preduzeća. Niš: Ekonomski fakultet.

Patterson, M. G. (1996). What is energy efficiency?: Concepts, indicators and methodological issues. Energy policy, 24(5), 377-390.

Pye, M., \& McKane, A. (2000). Making a stronger case for industrial energy efficiency by quantifying non-energy benefits. Resources, Conservation and Recycling, 28(3-4), 171-183.

Skumatz, L. A., Dickerson, C. A., \& Coates, B. (2000, August). Non-energy benefits in the residential and non-residential sectors-innovative measurements and results for participant benefits. In Proceedings of the 2000 ACEEE Summer Study on Energy Efficiency in Buildings, Vol. 8, p. 364, 8353-8364.

Worrell, E., Laitner, J. A., Ruth, M., \& Finman, H. (2003). Productivity benefits of industrial energy efficiency measures. Energy, 28(11), 1081-1098. 